\title{
PROPERTY RIGHTS OF HUSBAND AND WIFE: A BRIEF SURVEY
}

\author{
SURAJ KHETARPAL*
}

Under the Common Law a wife on marriage endowed her husband with all her worldly goods, and she also renounced all rights of ownership of any property she then, or in the future, might possess. The author examines the legislative departures from this position in England, Canada, Singapore and India. After establishing that the courts will apply "palm tree justice" where no definite intention as to the manner of ownership of property is ascertainable, the author concludes that this uncertainty in scope of judicial discretion should be removed as far as possible from the law.

"When hearts are united the division line between what is yours and what is mine has a tendency to fade away."

The law of matrimonial property has undergone a profound change in recent years. The twentieth century has seen the emancipation of women, particularly married women, and marriage has come to be looked upon as an equal partnership, particularly since many modern wives make a substantial financial contribution to it. Recent legislation and decisions in England on matrimonial property law present an opportunity for a re-examination of the problem and an attempt is therefore made to restate some aspects of the law.

\section{The Common Law}

Marriage is a partnership of love, affection and sympathy which should come to an end when these perish. When the parties wed, the husband vows in the wedding ceremony, "with all my worldly goods I thee endow," and the joint ownership should be jealously guarded both by written law and by popular sentiments. Consequently, when the husband and wife part, there should be a separation not only of heart and hand, but of goods as well, and unless there is such a separation, there should be no divorce. But, under the common law, "the law was the exact opposite-his wife endowed him, throughout their marriage, with all her worldly goods, and by marrying him renounced all rights to ownership of any property which she then possessed or might possess in the future." At common law, when a man and woman contract marriage their legal personalities are deemed to have merged, forming a single entity. The clearest and best exposition of the unity of husband and wife is that of Blackstone who said: ${ }^{3}$

By marriage, the husband and wife are one person in law; that is, the very being or legal existence of the woman is suspended during the marriage, or at least is incorporated and consolidated into that of the husband; under whose wing, protection and cover, she performs everything; and is therefore called in our law-French a feme-covert, femina viro go operata; is said to be covert-baron, or under the protection and influence of her husband, her baron or lord; and her condition during her marriage is called her coverture. Upon this principle of a union of person in husband and wife, depend almost all the legal rights, duties and disabilities, that either of them acquire by the marriage.

- LL.M., Ph.D. (London); Barrister, Gray's Inn, Associate Professor, Faculty of Law, The University of Alberta.

1 L. E. Beaulleu, Community of Property in the Law of Quebec (1939), 17 Can. Bar Rev. 486, 490.

2 Margaret Puxon, Ownership of the Matrimonial Home (1963), 107 Sol. J. 204. See also A. C. H. Barlow, Gifts and other Transfers Inter Vivos and the Matrimonial Home in Graveson \& Crane (ed.), A Century of Family Law 197, at 198 .

I I Blackstone, Commentaries on the Law of England 442 (1898). 
As a result of the doctrine of unity of legal personality, a married woman was, at common law, incapable of owning, acquiring or disposing of any property whether moveable or immoveable, and practically all her proprietary rights and interests were absolutely transferred to her husband or were jointly held by him. The husband was entitled to receive the rents and profits of all the freehold lands held by the wife as well as those subsequently acquired by her during coverture. If the husband predeceased the wife, she resumed the rights to all her freeholds. If the wife predeceased the husband, her estates of inheritance descended to her heir subject to the husband's right to retain seisin as tenant by courtesy. The wife could not dispose of her realty during coverture. Only the husband and wife together could jointly dispose of the whole estate. On marriage all choses in possession belonging to the wife also vested absolutely in her husband thus giving him the power to dispose of them inter vivos or by will. The only exception to this rule applied to the wife's paraphernalia (i.e. articles, such as clothing, jewellery etc., used by her during coverture). While her husband could dispose of these during his lifetime, he could not deprive her of them by bequest, and on his death they became her property and did not form part of his estate. However, the law relating to paraphernalia now appears to be obsolete. The wife's choses in action not reduced into possession did not vest in the husband immediately on marriage. If the husband dies before the choses in action were converted into possession, then the right of action survived in the wife. If the wife should die first then the husband could sue on those choses in action by taking out letters of administration. ${ }^{5}$

Such a state of affairs worked greater injustice to the wife, for a spendthrift husband could squander away all his wife's property, leaving the wife with no means of redress. At common law, husband and wife could not sue each other in either contract or tort because they would merely be suing themselves.

\section{Modification in Equity}

Equity as a court of conscience intervened to mitigate the rigour of the common law. The principle that "he who seeks equity must do equity" would be applied if the husband invoked the jurisdiction of the Court of Chancery to obtain the wife's equitable interest. This means that the court of equity would enforce the husband's right on condition that he settled part of the property for the benefit of the wife and children. This right, known as the "wife's equity to a settlement," could eventually be claimed after her death by her children. Secondly, the doctrine of the "separate estate" was invented by equity. This was the most important contribution of equity to the law of married women's property. Under this doctrine, property (realty or personalty) conveyed to a trustee for the "separate use" of a married woman would not vest in the husband but she would be entitled to hold and dispose of the

1 Masson, Templier \& Co. v. De Fries, [1909] 2 K.B. 831. For the historical background generally see E. L. Johnson, Family Law 74 (2d ed. 1965): P. M. Bromley, Family Law 420 (3d ed. 1966); B. D. Inglis, Family Law 530; O. Kahn-Freund, Matrimonial Property Law In England in W. Friedmann (ed.), Matrimonial Property Law 267; o. Kahn-Freudn, Inconsistencies and Injustices in the Law of Husband and Wife (1952). 15 Mod. L. Rev. 133; Megarry and Baker. Snell's Principles of Equity 563 (26th ed. 1966).

s See Fleet v. Perrins (1869), L.R. 4 Q.B. 500. 
property as if she were a feme sole. Thus with regard to her separate property, she was able in equity to deal with her property in any way she liked-she could dispose of it by will or inter vivos; and she could sue and be sued in a court of equity without the husband being made a co-plaintiff or a co-defendant. The equitable doctrine of "separate estate" could only be applied through an express and formal transaction such as a will or marriage settlement. This proved to be cumbersome and expensive; hence only the rich could afford it. Thirdly, equity also invented the doctrine of "restraint on anticipation" to protect her from transferring the separate estate to her husband on his persuasion. However, in 1949 legislation in England completely abolished all such restraints. ${ }^{\circ}$

\section{Legislation in England}

It was true that in the Victorian age the female was in need of protection and the doctrine of unity of husband and wife served its purpose, but it was certainly not desirable after the Victorian era as more and more women had income of their own. All these archaic common law rules have been swept away by legislation.' Nevertheless the social inequality remained until the 19th century when Parliament adopted the doctrine of "separate estate" and enacted the Married Women's Property Act, 1882. The effect of this Act was to put husband and wife on an equal footing as regards property. It provided that from that date all property owned by a woman at the time of her marriage and all property subsequently acquired by her was henceforth to be treated as if it had been contained in a marriage settlement so that it would be deemed her separate estate. ${ }^{8}$ It also enacted that: ${ }^{\circ}$

A married woman shall . . . be capable of acquiring, holding and disposing by will or otherwise, of any real or personal property as her separate property, in the same manner as if she were a feme sole, without the intervention of any trustee.

The Act was followed by a series of statutes (The Married Women's Property Act, 1884, 1893, 1907 and 1908) which made minor amendments. Full equality of status was not achieved at once. In the year 1935, the Law Reform (Married Women and Tortfeasors) Act which abolished the artificial concept of the "separate estate" was enacted.

The effect of this Act may thus be summed up in the words of Professor Kahn-Freund: ${ }^{10}$

Three principles are clearly stated in the Act of 1935-freed from the shackles of the conceptions of equity. The three principles are: equality of status and capacity of husband and wife in private law and in civil procedure, separation of property, and separation of liabilities. The conception of the married woman's statutory separate property has disappeared, and in present English law the acquisition and loss as well as the content and incidents of a married woman's property are in no way different from those of property vested in a man or in an unmarried woman.

Under the Act, a wife now has full power to enter into a contract either with a stranger or with her own husband. However, there is one important exception: any contract which is sought to be enforced between husband and wife must be shown to be something more than a

- Married Women (Restraint upon Anticipation) Act. 1949, 12, 13 and 14 Geo. 6, c.
78 . See also Megarry and Baker, op. cit. supra, n. 4, at 564-567.

7 The Matrimonial Causes Act, 1857, 20 \& 21 Vict., c. 85; The Married Women's Property Act, 1870, 33 \& 34 Vict., c. 93.

8 Married Women's Property Act, 1882, 45 \& 46 Vict., c. 76, ss. 2, 5.

9 Id., S. I (1). 
domestic arrangement. In certain cases, it will be assumed that the parties did not intend to enter into contractual relations. As Atkin L.J. pointed out: ${ }^{11}$

It is quite common, and it is the natural and inevitable result of the relationship of husband and wife, that the two spouses should make arrangements between themselves-agreements such as are in dispute in this action-agreements for allowances, by which the husband agrees that he will pay to his wife a certain sum of money, per week, or per month, or per year, to cover either her own expenses or the necessary expenses of the household and of the children of the marriage, and in which the wife promises either expressly or impliedly to apply the allowance for the purpose for which it is given. ... It constantly happens, I think, that such arrangements made between husband and wife are arrangements in which there are mutual promises, or in which there is consideration. ... Nevertheless they are not contracts, and they are not contracts because the parties did not intend that they should be attended by legal consequences. . . The consideration that really obtains for them is that natural love and affection which counts for so little in these cold Courts. The terms may be repudiated, varied or renewed as performance proceeds or as disagreements develop, and the principles of the common law as to exoneration and discharge and accord and satisfaction are such as find no place in the domestic code. The parties themselves are advocates, judges, Courts, sheriff's officer and reporter. In respect of these promises each house is a domain into which the king's writ does not seek to run, and to which his officers do not seek to be admitted.

The Act has also. abolished the husband's liability for his wife's contracts entered before marriage since he now acquires no property out of which he can meet her debts. It also abolished all his liability for her torts whenever committed, but there can be no action between husband and wife for torts not connected with the property. Lush J. in Hulton v. Hulton said: ${ }^{12}$

If a proceeding is necessary for the protection and security of a married woman's separate property, that proceeding can be taken against those who interfere with it, her husband as well as third persons. But proceedings against her husband for tort which do not come within the class of remedies for the protection and security of her separate property cannot be instituted by a married woman against her husband.

The objectionable feature in the 1935 Act was that it perpetuated the anomaly enacted in the 1882 Act, giving the wife the right to sue her husband in tort for the protection of her property, while a similar remedy was not available to the husband.

Since a husband could not sue his wife in tort, he was unable to get her out of the matrimonial house (of which he was the owner or tenant) by suing her in ejectment or trespass, unless divorce proceedings had been started and an injunction was obtained. ${ }^{13}$ The husband could, however, enforce his rights under the procedure laid down in section 17 of the 1882 Act. Under this section, a dispute between husband and wife pertaining to matrimonial property could be brought before the court by either spouse. This rule also worked injustice to third parties as can be seen in Drinkwater v. Kimber ${ }^{14}$ where it was held that if a third party injured a wife, even though the husband was partly to blame, the wife could recover the whole of her damage from the third party, but he (the third party) could not claim contribution from the husband because the husband could not be sued by the wife. Likewise the in-

11 Balfour v. Balfour, [1919] 2 K.B. 571, 578-579. See also Spellman v. Spellman, [1961] 2 All E.R. 498 (C.A.) where agreement as to ownership of a car was unenforceable and Thomas v. Thoma

12 [1916] 2 K.B. 642, 649.

See Halden v. Halden, [1966] 3 All E.R. 412. The husband was not entitled to turn her but unless he provided alternative accommodation. The wife did not have to show any legal or equitable interest in the property. Now the wife will be able to apply for an occupation order under the Matrimonial Homes Act, 1967.

14 [1952] 1 All E.R. 701. 
surers could escape their liability for the negligence of their insured if the tortfeasor and the insured happened to be married to each other. As a result of the complaints of the lawyers, ${ }^{15}$ this situation has been remedied by the Law Reform (Husband and Wife) Act, 1962. The husband and wife can now sue each other for torts not affecting their property.

The 1962 Act provides that each spouse shall have the same right of action against the other as though they were not married. An action in tort can be brought after the marriage has been dissolved for a tort committed during the subsistence of the marriage. But if an action is brought during the subsistence of the marriage, the court has a discretion to stay the action in two instances. Firstly, it may do so if it appears that no substantial benefit would accrue to either party from the continuance of the proceedings. Secondly, the court may stay the action if the question in issue could be more conveniently disposed of by an application under section 17 of the Married Women's Property Act, 1882, and the court may exercise any power which could be exercised on such an application. ${ }^{16}$ It is submitted that the proper remedy for settlement of property disputes between husband and wife is by an application under section 17 of the 1882 Act. ${ }^{17}$

The common law principle of the fictitious unity of husband and wife is almost completely abrogated. The married woman is virtually emancipated. One anomaly that still remains is the rule that a wife can have no domicile other than that of her husband, described by the Master of the Rolls in Formosa v. Formosa" as a "barbarous relic of the wife's servitude."10 Marriage will not affect the ownership of property vested in either spouse at the time of the marriage. The income of either spouse, whether from earnings or from investments will remain his or her own separate property, provided they do not pool their income into a common fund, in which case each spouse will have a joint interest in the fund.

\section{Married Women's Property Rights in Canada}

The lead taken by England on the concept of separate and equal rights of a married woman over her property was followed in all of the common law provinces of $\mathrm{Canada}^{20}$ as well as other parts of the British Commonwealth. ${ }^{21}$

16 See M. Puxon, Death of a Fiction (1962), 106 Sol. J. 742, 743

1610 \& 11 Ellz. 2, c. 48, s. 1.

17 This is discussed later in this paper.

18 (1962), 106 Sol. J. 629.

10 Puxon, loc. cit. supra, n. 15 , at 742

20 For Canada, See Clyde Auld, Matrimonial Property Law in the Common Law Provinces of Canada in Friedman, op. cit. supra, n. 4, at 239.

21 Alan Milner, Beneficial Ownership of the Matrimonial Home: Modern Trends in the British Commonwealth (1959), 37 Can. Bar. Rev. 473. In Singapore, the Women's Charter was promulgated in 1961 to provide for monogamous marriages for all persons resident or domiciled there other than Muslims. It amended and consolidated the laws relating to divorce, the rights and duties of married persons, the mainthe laws relating to divorce, the rights and duties of married persons, the mainof 1874. Section 20 of the Indian Succession Act XXXI of 1925 provides that no person shall by marriage acquire any interest in the property of the person whom he or she marries, nor become incapable of doing any act in respect of his or her own property which he or she could have done if unmarried. These acts do not apply to any marriage one or both of the parties to which professed, at the time of the marriage, the Hindu, Mahommedan, Buddhist, Sikh or Jain religion. Under the provisions of the Indian's Contract Act, 1872, a married woman is treated the same as a feme sole as far as her rights and liabilities arising under a contract are concerned. The capacity of a woman to contract is not affected by her marriage efther under the Hindu or Mahomedan Law; a Hindu married woman is liable on the either under the Hindu or Mahomedan Law; a Hindu married woman is liable on the
contract to the extent of her stridhanam (separate property) - see Nathubhai v. Javher, [1876] 1 Bom. L.R. 121. The Hindu Succession Act, 1956, s.14 has done away with inequality of property rights based solely on sex. 
In all common law provinces of Canada, a married woman has practically the same position as a feme sole with regard to civil capacity and property rights under the Married Women's Property Act. She is now entitled to hold and dispose of as her own separate property, the wages, earnings, money and property gained or acquired in any employment, trade or occupation in which she is engaged or which she carried on separately from her husband, or by the exercise of literary, artistic or scientific skill. ${ }^{22}$ A married woman has the capacity to enter a contract and she can sue or be sued in contract and tort, as if she were a feme sole. The property of a married woman is liable for all her debts and obligations and she is also subject to the provincial insolvency laws, and the Dominions Bankruptcy Act. ${ }^{23}$ An exception to the general rule that a husband is not liable for his wife's contract is found in the rule based in the common law that a wife may be deemed to be the agent of her husband and to have an implied authority to pledge his credit and to enter contracts for necessaries. ${ }^{24}$ A woman after her marriage continues to be liable for all her ante nuptial debts and liabilities to the extent of her separate property. A husband is generally not liable for the wife's ante nuptial contractual or tortious liabilities. ${ }^{25}$

A married woman has in her own name against all persons, including her husband, the same remedies and redress by way of civil or criminal proceedings for the protection of her property as if she were unmarried; but criminal proceedings concerning property shall not be taken by a wife against her husband while they are living together unless such property is taken by the husband when leaving or deserting or about to leave or desert his wife. A wife cannot, however, sue her husband in tort during coverture except for the protection of her separate property. ${ }^{26}$ Thus, she may sue her husband for such torts as detention or conversion of chattels belonging to her but not for such torts as libel, negligence or personal injury. ${ }^{27}$

Two other points need to be mentioned. First, there is nothing to prevent either a wife or a husband from suing for a tort committed by the other in the course of his or her employment as agent of some third party. In such a case it is the third party who is sued, and the immunity rule existing as between husband and wife does not protect him. ${ }^{28}$ Second, under the common law, if the husband was injured as the result of the combined negligence of his wife and a third person, the latter had to bear the whole loss and could claim no contribution from

22 Married Women's Act, R.S.A. 1955, c. 193, s. 2; Married Women's Property Act, R.S. B.C. 1960, c. 233, s.3; Married Women's Property Act, R.S.M. 1954, c. 156, s.3; Married Women's Property Act, R.S.N.B. 1952 , c. 140 s. 2; Married Women's Property Act, R.S.Nfld. 1952, c. 143, s. 2; Married Women's Property Act. R.S.N.S. 1952, c. 168, s. 3; R.S.Nfld. 1952, c. 143, s. 2; Married Women's Property Act, R.S.N.S. 1952, c. 168, s. 3;
Married Women's Property Act, R.S.O. 1960, c. 229, s.2; Married Women's Property Act, R.S.P.E.I. 1951, c. 92, s.2; Married Women's Property Act, R.S.S. 1965, c. 340, s.3. 28 e.g. The Married Women's Act, R.S.A. 1955, c. 193, s.4.

24 Scott v. Allen (1912), 26 O.L.R. 571.

25 The Married Women's Property Act, R.S.O. 1960, c. 229, s. 3; The Married Women's Act, R.S.A. 1955, c. 193, s. 7(b). The Married Women's Property Act, R.S.B.C. 1911, c. 152 contained provisions substantially similar to those of the Married Women's Property Act, R.S.O. 1960, c. 229 excepting the provisions of subsec. (2) and (3) of sec. 3 of the latter, exempting a husband from liability for a tort committed by his wife before or after marriage and debts and contracts incurred or entered into by her before marriage."-see J. J. Saucier, Q.C., Husband and Wife Legislation in Western Provinces of Canada During Past Fifty years (1964), Can. Bar. Assoc. 35.

26 Canadian Criminal Code, s. 275; R.S.A. 1955, c. 193, s.3; R.S.B.C. 1960, c.233, s. 13;

R.S.M. 1954, c. 156, s. 7; R.S.Nfld. 1952, c. 143, s.16; R.S.Ó. 1960, c. 229, s. 7; Married Women's Property Act, 1882, supra, n. 8, at s. 12; Law Reform (Married Women and Tortfeasors) Act, 1935, 25 \& 26 Geo. 5, c.30, s. 5, schs. 1, 2.

27 Ralston v. Ralston, [1930] 2 K.B. 238; Tinkley v. Tinkley (1909), 25 T.L.R. 264 (C.A.).

28 Broom v. Morgan, [1953] 1 Q.B. 597 (C.C.A.). 
the other. ${ }^{20}$ But under Alberta's Contributory Negligence Act, ${ }^{30}$ her degree of fault is determined and that contributory negligence is imputed to her husband and affects any damages assessed in his favour.

There is other important legislation in Canada which improves the rights of women. Provinces such as Alberta, British Columbia, Manitoba, Saskatchewan, New Brunswick, Nova Scotia and Ontario have dependants' relief legislation. The object of this legislation is to make provision for proper maintenance and support of dependants and widows. In all these provinces, if the husband died testate but without making adequate provision for the proper maintenance of his wife, then the Court has the power to provide allowances for her or order a different division of the estate. ${ }^{31}$

\section{Wife's Rights of Dower in Canada}

A passing reference should also be made to homestead legislation. In provinces such as Alberta, British Columbia, Manitoba, Saskatchewan and in the North West Territories, the common law right of dower has been modified by legislation. All these provinces have 'homestead laws' borrowed from the United States. ${ }^{32}$ The object of the legislation is to give a new right to the wife in respect of the husband's estate and guard her against injustice upon his death. The Act gives her a life estate in the homestead (the home) of her husband on his death. A homestead in Alberta is a parcel of land that consists of not more than four adjoining lots in one block in a city, town or village, used by the owner as his residence; or any other land not more than one quarter section of land used by the owner for the purpose of his residence. ${ }^{33}$ The husband cannot sell, exchange, mortgage or lease the homestead unless the wife consents in writing by the method prescribed in the Act. In Manitoba, the husband has a similar right in his wife's home. ${ }^{34}$ Section $3(1)$ of the Saskatchewan Homesteads Act assures the wife of independent legal advice and provides better safeguards in this respect. The wife must appear before either a district judge or a local registrar of the Court of Queen's Bench (or his deputy) or a registrar of land titles (or his deputy) or a solicitor or a justice of the peace or a notary public, be examined "separate and apart" from her husband, and acknowledge that she knows her right in the homestead and signs the instrument freely and without compulsion. No person who is interested in the preparation of the documents in the transaction is competent to take the acknowledgement. She has been given the right to protect her interest by a caveat forbidding any dealings by her husband with the homestead. In Alberta, it was held in Miller v. Miller ${ }^{35}$ that the Dower

29 Drinkwater v. Kimber, supra, n. 14.

30 R.S.A. 1955 , c. 56 , s. 5 .

31 The Family Relief Act. R.S.A. 1955, c. 109; Dependants Rellef Act. R.S.B.C. 1960, c. 378; The Testator's Family Maintenance Act, R.S.M. 1954, c. 264; The Dependant's Rellef Act. R.S.S. 1965, c. 128; Testator's Family Maintenance Act, S.N.S. 1956, c. 8; Dependant's Relief Act, R.S.O. 1960, c. 104; See Gordon Bale, Limitation on Testamentary Disposition in Canada (1964), 44 Can. Bar Rev. 367; see also Laskin, Dependants' Relief Legislation (1939), 17 Can. Bar. Rev. 181.

Other important legislation is the Deserted Wives' Maintenance Act. The purpose of this legislation is to enforce a husband's obligation to support his wife and children, if the husband has deserted her.

32 The Dower Act, R.S.A. 1955, c. 90; Wife's Protection Act, R.S.B.C. 1960, c. 407; The

Act, R.S.M. 1954, c. 65; The Homesteads Act, R.S.S. 1953, c. 11; See W. F. Bowker, Reform of the Law of Dower in Alberta (1955-1961), 1 Alta. L. Rev. 501.

33 The Dower Act, id., at s. 2 .

34 Supra, n. 32 , at s. 23 .

86 (1851), 2 W.W.R. 166. 
Act applies to every disposition of a homestead by a married person. Thus a wife who is judicially separated from her husband is deprived of the right she would have had under the Married Women's Act and the Domestic Relations Act, ${ }^{36}$ to dispose of their homestead, without any application to the court, as if she were a feme sole. In New Brunswick, a wife is not entitled to dower out of the lands of her ex-husband if she has been divorced by him on the grounds of adultery. ${ }^{37}$

On the other hand, in provinces such as Ontario, Nova Scotia and Prince Edward Island the common law system of dower which has been abolished in England still exists. In these provinces the wife has a life interest in one third of the real estate. She can exercise the option to have this estate set aside for her separate use for life or to have the income of the realty for life. ${ }^{38}$

\section{Comparison with the law in Singapore and India}

The main provisions of the Singapore Women's Charter, 1961, relating to the property rights of husband and wife are substantially the same as the current English law. ${ }^{30}$ In Singapore a husband can in no case sue his wife in tort, not even for the protection of his separate property, whereas in Malaysia the husband or wife may sue each other for the protection and security of their separate property. ${ }^{40}$ It has been held in Singapore that the court has no jurisdiction to adjudge a married woman bankrupt without proof that she has separate property at the time of the hearing of the bankruptcy petition. ${ }^{11}$ In India, the husband or the wife may sue the other in contract or in tort since Indian law does not recognise the principles of fusion of personality by subsequent marriage particularly among Hindus where the wife is treated as a part (rather half-part) of the body of the husband. ${ }^{42}$

36 Section 11(b) of the Domestic Relations Act, R.S.A. 1955, c. 89, provides, "the wife shall, during the continuance of the separation, be considered as a feme sole for the purposes of contracts .... and for all other purposes, and shall be reckoned as sui juris and as an independant person for all purposes, including the acquisition of a

new domicile distinct from that of her husband" " 322 that the courts have no power to grant a wife rights in her husband's homestead, for the protection exists only for wives and widows and not for divorced wives. In Robertson v. Robertson (1951), 1 W.W.R. 183 (Alta.), partition of the 'homestead' was denled under the Partition Act, 1868, but this was not followed in McWilliam v. McWilliam and Prudential Insur. of Amer. (1960). 31 W.W.R. 480 (Alta.).

37 R.S.N.B. 1952, c. 64.

38 R.S.O. 1960, c. 113, S. 19; R.S.N.S. 1954, c. 75; R.S.P.E.I. 1951, c. 46. In England, several changes were made by the Dower Act of 1833. The husband had a similar right in the land of his deceased wife which was called "tenancy by the curtesy." Both those rights were abolished in England in 1925. Curtesy is almost of little practical value in . Ontario and is obsolete in other provinces of Canada.

39 Thus, under s.48(1) of the Charter, a married woman has the capacity to acquire, hold and dispose of any movable or immovable property as her separate property as if she were a feme sole. A married woman has the capacity to enter into a contract in respect and to the extent of her separate property, and she can sue contract in respect and to the extent of her separate property, and she can sure not be joined with with her as a co-plaintiff or co-defendant (s. 47(3)). Every contract entered by a married woman otherwise than as an agent is deemed to be made in respect of and binds her separate property (s. 47(4)). Every woman has against all persons including her husband, the same civil remedies for the protection and security of her separate property as if she were a feme sole (s. 52). A woman after her marriage continues to be liable for all her ante nuptlal debts and liablities. A husband is generally not liable for the wife's ante nuptial contractual and tortious liabilities unless the husband acquired the wife's property (ss. 53, 54).

10 Women Ordinance (Malaysia) s. 4 and 9. In Singapore, the only civil remedy open to the husband is to bring a suit under section 57 of the Charter.

41 Re Lim Quee Geok, [1936] Malaya L.J. 3; Section 49 of the Charter provides that any money or estate of the wife lent or entrusted to her husband for the purpose of any trade or business carried on by him or otherwise shall be treated as assets of any trade or business carried on by him or otherwise shall be treated as assets husband's creditors may claim any gift or investments made by the husband to his wife which continues to be in the order and disposition or reputed ownership of the husband.

42 Ram Singh, Matrimonial Property Law among Hindus (1960), 6. J. Fam. Law 190. 
In Singapore, while the law gives equal rights and opportunities to women, many women, are still dependent on their husbands and fathers. This social factor affecting the status of women in the family was taken into consideration when the Women's Charter was enacted in 1961.43 Thus, the charter provides that the husband and wife are bound to cooperate with each other in safeguarding the interests of the union and in caring and providing for the children. The husband and the wife have the right separately to engage in any trade or profession or in social activities and have equal rights in the running of the matrimonial household. The wife has the right to use her own name separately.14

Section $\mathbf{5 7}$ of the Women's Charter in Singapore corresponds to section 17 of the English Married Women's Property Act, 1882, providing a simple procedure for settling disputes concerning property rights of spouses. Under this section, "in any question between husband and wife as to the title to or possession of property," either of them may apply for an order of the High Court and the judge "may make such order with respect to the property in dispute . . . as he thinks fit." The Court has extensive powers under this section. The court may order a spouse to give up possession of a house, to deliver up chattels, and to transfer shares and other choses in action or to pay over a specified fund, and it may even forbid him to dispossess the other spouse or to deal with the property in any way inconsistent with the other's rights. In India, the Hindu Marriage Act, 1955, likewise has provisions for determining property rights, and the court may dispose of property as it deems just and proper. However, the jurisdiction of the Matrimonial Court (District Court) constituted under the Act is confined to property presented to the parties at the time of the marriage and which belongs jointly to them. Other disputes relating to any property between husband and wife could be the subject of ordinary legal proceedings. ${ }^{45}$

\section{Property Acquired by the Spouses}

\section{Housekeeping Allowances}

In England, before the year 1964, the law was that any savings from housekeeping allowance prima facie belongs to the husband and not to the wife. Thus, in Blackwell v. Blackwell ${ }^{* 6}$ a sum of over $£ 100$ standing to the credit of the wife in her account at the Oxford Cooperative Society which represented moneys saved by the wife from a housekeeping allowance made to her was held to belong to the husband absolutely. Scott L.J. said: ${ }^{47}$

In my view there is no justification at all for the contention that, where a husband hands to his wife an allowance for housekeeping purposes, the husband is to be taken as a matter of law as presenting the savings out of that money to the wife for her sole use. The position in law will no doubt depend upon the evidence of what has passed between the parties. Here nothing was said at all

43 Ahmad bin Mohamed Ibrahim, The Status of Women in Family Law in the Federation of Malaya, Singapore and Borneo Territories, paper submitted to U.N. Seminar on the status of women in Family Law (Tokyo).

14 Women's charter (Singapore) s. 45.

45 Hindu Marriage Act, s. 27. It says. "In any proceeding under this Act the court may make such provisions in the decree as it deems just and proper with respect to any property presented at or about the time of marriage, which may belong jointly to both the husband and the wife." This act codifies the law relating to marriage among Hindus, and has made drastic changes in the Hindu Law of Marriage. The Act has given all Hindus, in specific circumstances the ability to obtain a decree of nullity or of dissolution of marriage. This is a revolutionary change in the Hindu Law, for under the old law, the marriage could not be dissolved in any circumstances. See S. T. Desal, Mulla Principles of Hindu Law 599-615 (1966).

to 1943$] 2$ All E.R. 579 (C.A.)

17 Jd., at 580 . 
and no arrangement was made by which the husband made a gift of the money to her. The result in such circumstances is that any savings remained the property of the husband. . . . It was, however, clear that the source of this money was the husband's weekly allowance and that was sufficient in the absence of any, evidence to the contrary that this money was still the property of the husband.

Similarly, in Hoddinott v. Hoddinott, ${ }^{48}$ it was held by the Court of Appeal, that furniture bought with the money won from a football pool belongs to the husband, because the stake money sent in was taken from the housekeeping allowance provided by the husband or the savings from it, although forecasting was the result of their joint effort. Denning L.J., dissenting from the majority view, held that the prize money could be considered either as the proceeds of skill in forecasting or as the proceeds of an investment made out of the savings from the housekeeping allowance. To his mind, the first alternative was correct. The prize money, being the result of their joint efforts, belonged to them jointly. As for the second alternative, His Lordship said: ${ }^{40}$

It is quite plain that the savings from the housekeeping allowance, before they are spent or invested, do not belong to the wife for her separate use. That was settled in cases before the passing of the Married Women's Property Acts, and, since those Acts, it has been held that if the wife takes the savings and converts them to her separate use, as for instance if she puts them into her own name without her husband's consent, she will be compelled to hand them over to her husband, who is the legal owner. However, I must not be taken to accede to the view that in point of equity the savings belong to the husband absolutely. It may be that they belong to both jointly, because they are as much due to the wife's good housekeeping as to the husband's earnings. . . . But if they invest money in their joint names, or buy furniture with it, which is obviously intended as a continuing provision in the future for the benefit of them together, in my opinion it should be presumed to have belonged to them jointly.

These cases, Blackwell v. Blackwell, ${ }^{50}$ and Hoddinott v. Hoddinott,, took no account of the fact that any savings from the housekeeping money were as much due to the wife's skill and economy as a housewife as to her husband's earning capacity. They are not in accord with the view of marriage as a working partnership. However, these cases are still followed in Canada, Singapore and India. But in England the dissenting judgment of Denning L.J. became the law when the Married Women's Property Act, 1964, was enacted to remedy such a situation. This is a significant step towards a system of community of property for it gave the wife an equal claim with her husband to any money saved, or property acquired, out of the "housekeeping allowances." The Act is based upon a unanimous recommendation of the report of the Royal Commission on Marriage and Divorce, 1955. . $^{52}$ "It is designed to give more effective recognition to the contribution of the wife to the marriage, particularly of the wife who is wholly or largely dependent upon the husband for financial support although she herself is contributing services to the marriage." ${ }^{53}$ Section 1 provides:

If any question arises as to the right of a husband or wife to money derived from any allowance made by the husband for the expenses of the matrimonial home or for similar purposes, or to any property acquired out of such money, the money or property shall, in the absence of any agreement between them to the contrary, be treated as belonging to the husband and wife in equal shares.

$48[1949] 2$ K.B. 406 (C.A.)

49 Id., at 415-416.

so Supra, n. 46; See also Wassill v. Wassill (1951), 4 W.W.R. 669.

61 Supra, n. 48.

52 Cma, 8678 para 701 (1956)

os Alec Samuels, The Married Women's Property Act, 1964 (1964), 108 Sol. J. 287. 
It must be noted that the Act applies not only to the savings from money provided by the husband for expenses of the matrimonial home or similar purposes, but also to any property acquired out of such money, and half of the property is now presumed to be a gift to the wife, thereby reversing Blackwell v. Blackwell and Hoddinott v. Hoddinott. Thus, it appears that many of the household items in the home such as furniture, television set, washing machine etc. bought with such allowances would presumptively belong to the husband and wife equally. However, this presumption can be rebutted if there is any agreement between the spouses. Secondly, the Act does not give an equal share to the husband in any surplus or proceed when the housekeeping allowance is provided by the wife. ${ }^{54}$ Thirdly, it must be noted that the main difficulty in applying this Act would be one of interpreting the phrase "expenses of the matrimonial home or for similar purposes." It is not clear what is included in the term "similar purposes." It seems it will be confined to allowances made as housekeeping allowances for the running of the house. In Tymoszczuk v. Tymoszczuk, s5 the first case reported after the enactment of the Act, an attempt was made to extend the wife's claims to money which bore little or no relation to the ordinary concept of a housekeeping allowance. The question was whether the Act applied to mortgage repayments made by the wife from the husband's earnings, which he handed over to her for the management of the household and whether she was entitled to claim a share of the house itself. It was held that the repayment of a mortgage on a house could not be regarded as "expenses of the matrimonial home," for these allowances were made in part-purchase of the matrimonial home and in part payment of a loan. Fourthly, the Act says, "if any question arises," money or property is to be treated as belonging to the husband and wife in equal shares, which means that the rule of survivorship will not apply. Alec Samuels aptly sums up the effect of this Act thus: ${ }^{8 B}$

It has been suggested that one result of the Act may be that the wife will now have an inducement to "skimp" the family's food, to give the husband corned beef instead of roast beef in order to acquire a half-share in the savings as a result of economy. This is a personal matter to be settled between them. He can retaliate by reducing the amount of the allowance. She still has no enforceable right to maintenance, eg., on the ground of wilful neglect to maintain, so long as they are still living together (Matrimonial Proceedings (Magistrates' Courts) Act, 1960, s. 7(1).)

\section{Wedding Presents}

There are no fixed rules of law to determine the ownership of wedding presents. Reference must be made to the intention of the donor. Where there is evidence of an intention on the part of the donor, it may be that the wedding presents have been given either to one spouse or the other or both; but where no intention is clear the court is fully entitled to draw the inference that money and gifts in kind originating from the husband's side of the family or from friends of the husband were intended for him, and those from the wife's side of the family or her friends for her. Thus, there is no presumption that wedding presents

54 Miss O. M. Stone, Married Women's Property Act, 1964 (1964), 27 Mod. L. Rev. 576 She refers to $R$ e Sylvester, [1941] Ch. 87 in this connection. The Royal Commission recommended that savings made from housekeeping allowances, to which either spouse or both contribute. should belong to both spouses equally, unless they have spouse or both contribute, shou
otherwise agreed. Supra, n. 52 .

86 (1964), 108 Sol. J. 676.

50 Samuels, op. cit. supra, n. 53 at 287-88. 
are given jointly to both spouses, nor is there a presumption that gifts from the husband's relatives and friends belong to the wife, although either of these two solutions may be the correct one in any given case..$^{57}$

It is submitted that some presents, such as jewellery, which are given by the husband's relatives are clearly designed for the wife, and hence they should be regarded as her property.

There is another possible position that property which is given at the time of the wedding to one spouse or the other may be found to be joint property by looking at the subsequent conduct of the parties. In such circumstances the property may be divided equally between the spouses. This situation arose in Newgrosh v. Newgrosh, ${ }^{58}$ where a suite of bedroom furniture was given to the husband by his wife and a suite of drawing room furniture was bought by the wife with her own money. After the wedding the spouses lived together and used both suites of furniture; it was held that both suites of furniture were joint property.

Thus in determining the ownership of wedding presents, the court must consider, so far as there is evidence before it, who gave the present, whether he indicated any intention either expressly or impliedly, the nature of the present, and the use to which it has been put by the parties since the wedding.

\section{Chattels}

In deciding ownership of chattels, one must consider the nature of the property or chattels concerned. Denning L.J. in Newgrosh v. Newgrosh said: 50

In the ordinary running of a home, where the parties agree to buy clothes or

furniture, they may also agree to whom it is to belong; but if, as so often happens, they have left that unsaid, the title to it depends as a rule on the nature of the property bought or the investment made. It does not necessarily depend on who provides the money. If clothes are bought for the wife they are of course hers.

It is therefore submitted that where the property in question is used mainly or solely by one spouse, a presumption arises that this property belongs to that spouse; but where the property is used by both together, it is joint property. As these are mere presumptions they can be rebutted by evidence of a contrary intention at the time of the purchase of the chattels, or of a subsequent gift of them by one spouse to the other. ${ }^{\circ 0}$

As between the spouses, there is no relaxation of the general principle that delivery is necessary for the legal gift of a chattel. In order to constitute a gift by one spouse to the other, it must be shown that transfer of possession took place, unless the gifts were by deed, as equity will not perfect an imperfect gift. Words spoken or written or conduct on either side may be evidence of the intention of making a gift but mere words are no substitute for delivery. ${ }^{61}$

\footnotetext{
s7 Samsoin v. Samson, [1960] 1 W.L.R. 190.

58 (1950), 100 L.J. 525 (C.A.).

50 Ibid.

60 E. L. Johnson, supra, n. 4, at 101.

$61 \mathrm{Re}$ Cole, A Bankrupt, [1963] 3 All E.R. 433 (C.A.) For a powerful criticism of this case, see J. W. A. Thornley's case note in [1964] Camb. L.J. 27. For the avoidance of gifts to a wife, reference may be made to section 10 of the Married Women's Property Act, 1882, which says ". . And nothing in this Act contained shall give validity as against creditors of the husband, to any gift, by a husband to his wife of any property, which, after such gift, shall continue to be in the order and disposition or reputed ownership of the husband or to any deposit or other investment
} 


\section{Income-pooling of resources}

Nowadays, property separately owned by the spouse does not pose any difficulty. If any property is purchased by one spouse with his money, it presumptively belongs to the purchaser. Likewise, the income of either spouse, whether arising from earnings or from investments will prima facie remain his own money. The main problem is centred around property jointly owned by husband and wife. Such joint ownership may occur when spouses pool their resources together.

This situation arose in Jones v. Maynard ${ }^{02}$ where the husband and wife pooled their income into a joint account. The husband, whose contributions were greater than the wife's, from time to time withdrew money and invested it in his own name. It seemed that the parties never made any clear agreement as to their respective rights in the account. Later, the marriage ended in a divorce and the wife claimed for a half share in the bank account and the investments purchased out of it. It was held that the account and the investment must be equally divided between them. Vaisey J. said: ${ }^{\text {ss }}$

I do not believe that, when once the joint pool has been formed, it ought to be, and can be, dissected....

In my view a husband's earnings or salary, when the spouses have a common purse, and pool their resources, are earnings made on behalf of both; and the idea that years afterwards the contents of the pool can be dissected by taking an elaborate account as to how much was paid in by the husband or the wife, is quite inconsistent with the original fundamental idea of a joint purse or a common pool.

In my view the money which goes into the pool becomes joint property. The husband, if he wants a suit of clothes, draws a cheque to pay for it. The wife, if she wants any housekeeping money, draws a cheque, and there is no disagreement about it.

That being my view, it follows that investments paid for out the joint account, although made in the name of the husband, were in fact made by him in his own name as a trustee as to a moiety for his wife. If the investments out of the joint account had been made in the name of the wife alone, there is no doubt that the ordinary presumption of law would have applied and she would have been entitled to the investments; but as they were made in the name of the husband, it seems to me that the assumption of half and half is the one which I ought to apply.

The rule of fifty-fifty as applied by Vaisey J. in Jones v. Maynard was followed by the Supreme Court of Nova Scotia in the very recent case of Re Cameron, ${ }^{64}$ where there was a question of ownership of bearer debentures and bonds found in a safety deposit box rented in the name of the husband and wife as tenants in common, while there was no indication that such securities were the property of one or the other of the parties. ${ }^{05}$

of moneys of the husband made by or in the name of his wife in fraud of his creditors; but any. moneys so deposited or invested may be followed as if this Act had not passed." Its meaning remains obscure, although there was some discussion had not passed." Its meaning remains obscure, althou

62 [1951] Ch. 572.

63 Id., at 575; see also S. v. S., [1954] 2 D.L.R. (2d) 765, 774-5, where the Manitoba Court of Appeal has expressed the same Idea.

04 [1967] 62 D.L.R. (2d) 389.

65 Id., at $402-403$ it was stated.

"The lease agreement in each case deals only with the rights of the box holders and the bank, as between the holders as lessees and the bank as lessor, and the agreement does not purport to deal with ownership of the property from time to time contained in the safe deposit boxes, or to deal in any way with the respective rights of the lessees to such contents."

Re Peterson's Estate (1927), 214 N.W. 418; 239 Mich 452 was followed in Re Cameron. In $R e$ Cameron, there was no evidence to show who provided the money which was used to purchase the bearer debentures and bonds. They were apparently purchased with money delivered from his or her separate estates. Her claim to the title to the whole was not corroborated by other evidence. It was held that such investments should be regarded as being owned in equal shares.

In Re Cameron, it was also held that, where a husband bought corporate shares for his wife, registered them in her name and placed them in a safe deposit box 
It appears from the decided cases that to constitute a "common purse," there must be a fund intended for the use of both spouses and from which either may withdraw money. Where both parties contribute to the fund, this intention will be imputed to the parties in the absence of any other agreement. If, however, the money is overdrawn from such a bank account, then the presumption is that as between themselves each spouse should bear the debt. ${ }^{66}$ But where the fund is comprised of income from one spouse alone, this will continue to be his or her exclusive property, unless there is an express intention to establish a common fund. Thus, where an authority is given to the other spouse to draw on this fund, this will not in itself create a joint interest for this may be done merely for the convenience of the other. A statement of the law to this effect can be found in Marshal v. Crutwell ${ }^{87}$ where a husband in failing health permitted his wife to draw a cheque at his direction, and the proceeds were applied in payment of household and other expenses. It was held that his estate and not the wife was entitled to the balance of the money in the banking account.

In the case of a joint bank account which was not opened for some special purpose, each spouse is entitled to draw on it for his own benefit and the balance belongs to the survivor on death. If one spouse purchases a chattel for his own benefit or an investment is made in his or her own name with the money withdrawn from the common purse, that chattel or investment prima facie belongs to the person in whose name it is purchased or invested. ${ }^{08}$

\section{The Disputes over Title to Property-Palm Tree Justice in England}

A considerable amount of litigation has centered on the ownership of the matrimonial home, or its contents, since very often it is the only valuable asset owned by the parties. When spouses buy the property during marriage, it is not unusual for them to make the question of the ownership clear at the time so as to avoid any dispute of ownership if the marriage breaks up. In 1882, when Parliament declared that a wife was entitled to have property of her own, it enacted that in any question between husband and wife as to the title to, or possession of, property the court was to decide the matter as it thought fit. Parliament laid down no principles for the guidance of the courts, but left them to work out the principles themselves. ${ }^{60}$

However, there are at least three ways of settling the disputes when the intention of the parties is not made clear at the time of the purchase of the property. The first is by use of the presumption of a resulting trust, the second by use of the presumption of advancement, and the third is by the principle of "Palm Tree Justice." The first two were created by equity and may be briefly described here. ${ }^{70}$ The general rule is that where a person purchases something "in the name of a third person" a trust results for the purchaser (or his representatives). This is, however, not an absolute rule, but varies according to whether the

in their two names as tenants in common and equally accessible to them both, the principle of advancement operated, unless rebutted, to vest the securities in the wife immediately

66 Re Shaw (1906), 94 L.T. 93

67 (1875), L.R. 20 Eq. 328; See also Harrods, Ltd. v. Tester, [1937] 2 All. E.R. 236 (C.A.).

68 See Re Bishop, National Provincial Bank Ltd. v. Bishop, [1965] Ch. 450.

69 Supra, n. 15.

70 See Megarry \& Baker, op. cit. supra, n. 4, at 192-198. See also Inglish, op. cit. supra, n. 4 , at $534-538$. 
conveyance is to a stranger or to a relation of the purchaser. Thus, if the conveyance is to a stranger, there is a presumption that the purchaser did not intend to benefit the transferee. The trust of legal estate, whether taken in the name of the purchaser and others jointly or in the name of others without that of the purchaser, results to the man who advances the purchase money. But the presumption is rebuttable by parole evidence showing that the nominal purchaser was intended to take the beneficial interest. ${ }^{11}$ As early as 1788 it was said: ${ }^{72}$

The clear result of all the cases, without a single exception, is, that the trust of a legal estate, whether freehold, copyhold, or leasehold; whether taken in the names of the purchasers and others jointly, or in the name of others without that of the purchaser; whether in one name or several; whether jointly or successive, results to the man who advances the purchase-money. This is a general proposition supported by all the cases, and there is nothing to contradict it; and it goes on a strict analogy to the rule of the common law, that where a feoffment is made without consideration, the use results to the feoffor. It is the established doctrine of a Court of equity, that this resulting trust may be rebutted by circumstances in evidence.

However, if a husband buys the property with his own money and has conveyed it into his wife's or his child's name the presumption is the other way-i.e. that he intended to make a gift to the wife or child. ${ }^{73}$ The presumption of the advancement will be raised in all cases where the purchaser (or donor) is under an obligation to support or to make certain provisions for the persons concerned. This is because equity recognizes a husband's duty to maintain and advance his wife and child, and any such transaction is presumed to be in performance of that duty. ${ }^{\text {i4 }}$ As this is only a presumption, it may be rebutted if the intention is a fraudulent one, for "he who comes to equity must come with clean hands."75 The presumption of advancement does not apply where the husband has joined as surety to guarantee a debt due by the wife to the mortgagee. ${ }^{76}$ There will be no presumption of gift if the wife has not given consent to her husband to receive her property. ${ }^{77}$ If the presumption in favour of advancement could be rebutted, the presumption in favour of a resulting trust would apply and the husband would be beneficially entitled to the property. It must be pointed out that either presumption could be displaced. George Jessel M.R. states the law in this way: ${ }^{78}$

71 Heard v. Pilley (1869), 38 L.J. Ch. 718.

72 Dyer v. Dyer (1788), 2 Cox 92; 30 E.R. 42, per Eyre C.B

73 Shephard v. Cartwright, [1955] A.C. 431; Jackman v. Jackman (1959), 19 D.L.R. (2d) 317 (S.C.C.): Sopow v. Sopow (1958), 24 W.W.R. 625 (B.C.) Redgrove v. Unruh (1961), 35 W.W.R. 682 , aff'd. 39 W.W.R. 317.

74 There is no such presumption in equity in regard to an lllegitimate child, or as between a mother and her legitimate child while the father is living. In such cases, the presumption is that there is a resulting trust; but the facts of the case may show that he is loco parentis to his illegitimate son i.e. he has taken upon himself the duty of providing for the child. See Bennet v. Bennet (1879), 10 Ch.D. 474; Edwards v. Bradley, [1956] O.R. 225. rev'd [1957] S.C.R. 599.

75 Gascoigne $\mathrm{v}$. Gascoigne, [1918 $1 \mathrm{~K}$ K.B. 223 . See also Re. Emery's Investment Trusts, [1959] 1 All E.R. 577, and Chettiar v. Chettiar, [1962] 1 All E.R. 494 (P.C)..

io In Re Salisbury-Jones, [1938] 3 All E.R. 459. If he made the payments in pursuance of a legal obligation to the mortgagee, he would be entitled to claim such sums against the principal debtor (i.e. from his wife) unless there was a clear intention at the time of the giving of the guarantee that there was to be no reimbursement or a special agreement that the husband was to bear the liability. See also Anson v. Anson, [1953] 1 Q.B. 636, where the sum of $\$ 500$ was paid by the husband under his guarantee of his wife's overdraft and it was held not to be a gift. The husband was therefore entitled to claim the money for he made it plain to his wife that he was not going to relleve her of the draft, but to solve the immediate banking account.

i7 Re. Flamank, Wood v. Cock (1890), 49 Ch. 461.

In certain circumstances, a gift between spouses may be inferred from a course of dealing, as in Caton v. Rideout (1849), 1 Mac \& G. 599; 41 E.R. 1397. In this case, a married woman who was entitled to the dividends of certain stock for her separate use allowed those dividends for some fourteen years to be paid into her husband's account. It was held that this amounted to evidence of a direction on her part that account. It was held that

78 Marshal v. Crutwell, supra, n. 67, at 329. 
The mere circumstance that the name of a child or a wife is inserted on the occasion of a purchase of stock is not sufficient to rebut a resulting trust in favour of the purchaser if the surrounding circumstances lead to the conclusion that a trust was intended. Although a purchase in the name of a wife or a child, if altogether unexplained, will be deemed a gift, yet you may take surrounding circumstances into consideration, so as to say that it is a trust, not a gift.

On the other hand, if the wife purchases property or makes an investment in the husband's name, there is no such presumption of advancement because she is under no obligation to maintain or advance him. The husband is regarded as holding the property or investment as trustee for his wife unless there is actual evidence to the contrary. ${ }^{79}$ It may be argued that the husband should not suffer this setback and should be placed on the same footing as the wife. In short, the presumption of advancement should operate in the husband's favour in the same way as it operates in the wife's favour. ${ }^{80}$

It is quite common for one of the spouses to provide the purchase money and then the property is conveyed into the spouse's joint names. Let us take the case of the husband who buys the property in his own name and has it conveyed into the joint names of himself and his wife. In such a case, the presumption of advancement applies, i.e. he intended a gift to his wife of one half the beneficial interest and, in the absence of evidence of any other intention at the time of the conveyance, the wife is entitled to claim half the proceeds of the property. If the wife, however, provides the purchase money and has it conveyed into their joint names, the effect is quite different; a resulting trust is presumed in her favour and she is entitled to claim the whole of the proceeds of sale. $^{81}$

In the case of a family asset such as the home or furniture acquired for the joint use of the spouses, the presumption of advancement can be easily rebutted. It has been said of the presumption that "it has got only a precarious future existence." 82

The third method of settling the dispute over the matrimonial property arises in circumstances where each spouse has contributed continually over a long period by making payments towards the purchase of the house and its contents. It is impossible to make a clear division of the property as no definite intention as to the manner of ownership is ascertainable. Such disputes are very well dealt with by the principle which has been described as "Palm Tree Justice." "Usually this simply amounts to the Judgment of Solomon; neither the parties nor the court knows what they really intended, the principle of "Equality is Equity" is applied and each is given an equal share irrespective of his or her contribution." ${ }^{83}$ In the leading case of Rimmer v. Rimmer, Romer L.J. said: ${ }^{84}$

.. cases between husband and wife ought not to be governed by the same strict considerations, both at law and in equity, as are commonly applied to the ascertainment of the respective rights of strangers when each of them contributes to the purchase price of property, and, secondly, that the old established doctrine that equity leans towards equality is peculiarly applicable to disputes of the character of that before us where the facts, as a whole, permit of its application.

79 Mercier v. Mercier, [1903] 2 Ch. 98.

81 Wupra, n. 52 , at para. 703 . 2 . Steele, (1814) 2 V. \& $388 ; 35$ E.R. 366.

82 Note on Silver v. Silver, [1958] 1 All E.R. 523 in 74 L.Q. Rev. 165. See also Fish v. Fish (1966), 110 Sol. J. 228.

84 [1952] 2 All E.R. 863, 870 (C.A.). 
In England, the maxim "Equality is Equity" was applied in a series of cases following Rimmer v. Rimmer and it now seems to be fairly well established there that both spouses are entitled to share equally if the matrimonial home is purchased by their joint efforts and contributions. ${ }^{85}$ In such cases the court, however, still has a discretion. As Lord Pearce pointed out in Strachan v. Strachan: ${ }^{86}$

Reference has been made to an observation of Bucknill L.J. in Newgrosh v. Newgrosh ${ }^{87}$ with which I entirely agree, as to the wide power of the court to do what is fair and just under section 17. Although it must not contravene legal principles, yet, as Bucknill L.J. pointed out, this is a species of "palm tree justice," and the court is trying to arrive at what is fair and just in the special circumstances of the case. Financial dealings between husband and wife vary very much, and are so difficult to pin down with accuracy after, perhaps, the lapse of many years that the court has to do its best to arrive at some fair solution between them.

Since the court has this discretion, it does not follow that the court will always order the proceeds of the sale of the home to be divided equally even where there is an express.joint tenancy. ${ }^{88}$

Some extension of the power exercised in Rimmer's case to divide the property purchased in the husband's name equally between the spouses could be seen in Fribance v. Fribance, ${ }^{89}$ where the husband saved his money to buy the house, whereas the wife used her earnings to defray household expenses and provide clothing for the children. In the circumstances it appeared to be the most convenient type of arrangement. Since he alone contributed financially in the purchase of the house, should he alone be entitled to claim the whole beneficial interest in the house? On principle it would be wrong to accept this argument. Since the house was acquired for the benefit of the whole, it should belong to them in equal shares. ${ }^{90}$ Denning L.J. shared this view when he said: ${ }^{91}$

In the present case it so happened that the wife went out to work and used her earnings to help run the household and buy the children's clothes, whilst the husband saved. It might very well have been the other way around... The title to the family assets does not depend on the mere chance of which way round it was. It does not depend on how they happened to allocate their earnings and their expenditures. The whole of their resources were expended for their joint benefit.... and the product should belong to them jointly. It belongs to them in equal shares.

In the later decision of Allen v. Allen ${ }^{92}$ the husband paid for the

$85 \mathrm{Cobb}$ v. Cobb, [1955] 2 All E.R. (C.A.) and Fribance v. Fribance, infra, n. 89. See also Fennell v. Fennell (1966), 110 Sol. J. 707, where Lord Denning M.R. said that the law was stated in Silver v. Silver, supra, n. 82, and Fish v. Fish, supra, n. 82 . Although a house might be conveyed into the name of a wife, when it was intended to be the house for the parties for their joint lives, any presumption of advancement was very slight. When a house which was intended to be the matrimonial home was taken in the name of one or other of the spouses, where both had contributed to the purchase by their joint efforts, the presumption in the absence of any evidence to the contrary was that it belonged to them both beneficially in equal shares. Russell L.J. said that he could not agree with the statement about the presumption. See also M. Puxon, loc. cit. supra, n. 2.

86 [1965] 1 W.L.R. 646, 649.

87 Supra, n. 58.

88 Hine v. Hine, [1962] 3 All E.R. 345 (C.A.)

89 [1957] 1 All E.R. 357 (C.A.).

90 See O. M. Stone, Matrimonial Property Law-The Scope of sec. 17(1957), 20 Mod L. Rev. 281. Bromley, op. cit. supra, n. 4, at 448-449.

O1 Supra, n. 89, at 360 .

92 [1961] 3 All E.R. 385 (C.A.). This decision of the court of Appeal is llable to be misleading unless its further decision, reported in (1962), $106 \mathrm{Sol}$. J. 174 is taken into account. The Court of Appeal unanimously held that the case should be sent back to the judge as to his findings concerning the parties intention when the house was bought. The distinction lies between these two situations: (1) If the spouses was bought. The distinction lies between these two situations: (1) If the spouses all the expenses, including the mortgage instalments were met, then the house was intended to be a joint venture. (2) However, where the husband had to pay for the house and the wife was asked herself to earn money towards other expenses, then the house belonged to him alone. The second alternative seems somewhat unfortunate. See Bromley, op. cit. supra, n. 4, at 449, where he sald "it is to be hoped that the court will not lay such emphasis on domestic agreements of this sort in the future." 
house wholly with his own money while the wife helped him to achieve this by providing for the household expenses. This alone would not have given her any beneficial interest in the house, but it was found that at the time when the house was bought it was intended to to form part of a joint venture, and the wife was therefore entitled to a half share.

The wife would not be entitled to claim a share in the beneficial ownership of the house and the proceeds thereof if she did not make any substantial contributions either directly or indirectly to the purchase of a house. It should be financial contributions, for the court would not take into account her services in kind as a housekeeper..$^{93}$ In any case her contribution must be substantial. Lord Denning M.R. in Tulley v. Tulley ${ }^{94}$ said:

If the husband paid all the instalments and the wife by her earnings paid all the household expenses, she would indirectly be contributing to the acquisition of the house and the court might well say or infer that the common intention was that it should be joint property as a family asset, and that she would have a claim to be considered under section 17 , whether her contribution was direct or indirect, provided it was substantial.

The palm tree justice under which Rimmer v. Rimmer was decided has borne some very curious results, for it seems "a husband can obtain a beneficial interest in his wife's real property without doing more than put a lick of paint on the walls."95 In Appleton v. Appleton ${ }^{96}$ as a result of the husband's work in renovation of the house purchased by the wife in her name, the value of the house was improved and it was held by the Court of Appeal that he was entitled to some percentage of the proceeds of sale based on the amount by which his work had enhanced the value of the house. However, Lord Upjohn in National Provincial Bank Ltd. v. Ainsworth ${ }^{97}$ and also Russell L.J. in Jansen v. Jansen $^{98}$ regarded Appleton v. Appleton ${ }^{90}$ as incorrectly decided; the husband, in the absence of some agreement, could have no claim in the house. But Lord Denning M.R. in Jansen v. Jansen ${ }^{100}$ said that his Lordship did not think that Lord Upjohn had meant that a contractual agreement was necessary in order to give the husband an interest. Parties living together in amity did not make legal contracts enforceable in a court of law; and where existing rights were not clear the court would decide under section 17 what was fair and just between them.

\section{Proceedings in England under the Married Women's Property Act, 1882, Section 17}

Under this section the court has very wide discretionary powers to settle property disputes between husband and wife. This jurisdiction is frequently invoked following separation or divorce proceedings. The application is normally heard by the master or registrar of the court, and an appeal lies from his decision to the Court of Appeal. It provides that "in any question between husband and wife as to the title to or

\footnotetext{
98 Bromley, op. cit. supra, n. 4 and other articles thereunder.

94 (1965), 109 Sol. J. 956

95 (1964), 108 Sol. J. 997.

86 [1965] 1 All E.R. 44; [1965] 1 W.L.R. 25.

97 1965] A.C. 1175, 1236. See Pettitt v. Pettitt (1968), 112 Sol. J. 111; c.f. Butlon v. Butlon (1968), 112 Sol. J. 112. See also (1908), 112 Sol. J. 102.

98 [1965] 3 All E.R. 363 (C.A.).

90 "The husband (like a stranger) would probably have to prove an express agreement or understanding between the parties that he should be pald rather than leave the court to infer this from their relationship as husband and wife". See Bromley op. cit. supra, n. 4 , at 450 .

100 Supra, n. 98.
} 
possession of property" either of them may apply for an order to the High Court or a county court and the judge "may make such order with respect to the property in dispute . . . as he thinks fit."

The court under this section can order either spouse to give up any property to the other, or order a sale, or order money payments to be made by one spouse to the other in compensation for property. ${ }^{101}$ This section, although it is almost 85 years since it has been enacted, is still the subject of acute judicial divisions of opinion. ${ }^{102}$ Thus, it has been said (this may be called a wide view) with reference to section 17 that the court has a "free hand to do what is just." In Hine v. Hine Lord Denning M.R. said: ${ }^{103}$

It seems to me that the jurisdiction of the court over family assets under section 17 is entirely discretionary. Its discretion transcends all rights, legal or equitable, and enables the court to make such order as it thinks fit. This means, as I understand it, that the court is entitled to make such order as appears to be fair and just in all the circumstances of the case.

On the other hand, it has been said .(which may be called the narrow view) that this is "purely procedural and the duty of the court is merely to ascertain established rights and give effect to them." Romer L.J. in Cobb v. Cobb said: ${ }^{104}$

I know of no power that the court has under section 17 to vary agreed or established titles to property. It has power to ascertain the respective rights of husband and wife to disputed property, and frequently has to do so on very little material, but where, as here, the original rights to properly are established by the evidence, and those rights have not been varied by subsequent agreement, the court cannot, in my opinion, under section 17 vary those rights merely because it thinks that in the light of subsequent events the original agreement was unfair.

Russell L.J. favoured this view in Jansen's Case: ${ }^{105}$

My own view remains that section 17 is merely a procedural section, designed to achieve an inexpensive and private solution of property disputes between husband and wife: that it confers no jurisdiction which did not previously exist as a matter of substantive law; that it merely recognized the fact that in some cases between husband and wife one must do one's best to deal with some situations by applying a knife to the Gordian knot, as Lord Upjohn remarked in the National Provincial Bank Case.

There is a third view that, whereas the court cannot disregard a claim of legal rights in matters concerning property jointly acquired or jointly used, the court has a wide discretion to deal with it in such manner as will be fair and just as between the parties, having regard to the whole history of the acquisition and use of the property in question and to all the surrounding circumstances of the matrimonial life of the parties. This view is shared by Bucknill L.J., Lord Denning M.R. and Lord Upjohn. ${ }^{108}$

Bucknill L.J. in Newgrosh v. Newgrosh said: ${ }^{107}$

That [s.17] gives the judge a wide power to do what he thinks under the circumstances is fair and just. I do not think it entitles him to make an order which is contrary to any well-established principle of law, but subject to that, I should have thought that disputes between husband and wife as to who owns property which at one time, at any rate, they have been using in common are

101 Lee v. Lee, [1952] 1 All E.R. 1299 (C.A.): Matrimonial Causes (Property and Maintenance) Act, 1958, s. 7 now confirm that the court has power to order a sale of the property. A loan by one spouse to the other could not be recovered under this section-see Crystall v. Crystall, [1963] 2 All E.R. 330 (C.A.). See (1967) 111 Sol. J. 819, 937. The new Matrimonial Homes Act, 1967, supra, n. 13, does not deal with the problem of whether the court should order the sale of the jointly owned home on the breakdown of the marriage.

102 Lionel Rosen, Palm Tree Justice (1966), 110 Sol. J. 239.

103 Supra, n. 88 at 347.

104 [1955] 1 W.L.R. 731, 737.

105 Supra, n. 98 at 370.

100 Lord Úpjohn in the National Provincial Bank Case, supra, n. 97.

107 Supra, n. 58. 
disputes which may very well be dealt with by the principle which has been described here as 'palm tree justice'. I understand that to be justice which makes orders which appear to be fair and just in the special circumstances of the case.

It seems Lord Denning M.R. has now changed his views. In Jansen v. Jansen he said: ${ }^{108}$

Where the existing rights can clearly be ascertained, effect must be given to them; but where it is not possible to ascertain them, the court can only do what the statute says it should do, that is, make such order "as it thinks fit".

But it seems clear that the court has no power under section 17 to vary established titles. ${ }^{109}$

\section{Palm Tree Justice in Canada}

All the Common law provinces of Canada except Alberta have provisions similar to section 17 of the English Married Women's Property Act, 1882.110 It provides a simple procedure for settling disputes concerning property rights of spouses. It might be argued that a wide power is conferred upon the judge to make an order in dispute between spouses as to title to property, however the discretionary use of such power has not developed the same way in Canada as it has in England. ${ }^{111}$

The idea of the joint asset doctrine as in Rimmer v. Rimmer and Fribance v. Fribance ${ }^{112}$ was stressed in Canada in Mitchelson v. Mitchelson ${ }^{113}$ and Atamanchuk v. Atamanchuk. ${ }^{114}$ It was held in these cases that, where the husband and wife worked together to acquire property and the property is in the husband's name, it is held by the husband as a trustee for the wife to the extent of one half. Duval J. said: ${ }^{115}$

Where there is a joint purse between husband and wife and a common pool into which they put all their resources, it is not consistent that the assets should thereafter be divided with reference to their respective contributions, crediting the husband with the whole of his earnings and the wife with the whole of her earnings. It would be impossible to make any such calculation. It is also clear that when a husband and wife, by agreement, work together in operating a farm and the properties are in the husband's name, he will be held to hold title thereto as a trustee for her to the extent of one-half."

On the other hand, it was held by the Supreme Court of British Columbia in Sopow v. Sopow ${ }^{118}$ and by the Appellate Division of the

108 Supra, n. 98, at 366; see also Fish v. Fish, supra, n. 82, at 228 where Lord Denning M.R. said, "It was now settled that under $s$. 17 the court did not interfere with rights once they were established between the parties, but if they were not established or were uncertain, the court's discretion under $\mathrm{s}$. 17 came into play and, in the absence of any clear division between the parties, the ordinary rule in the case of family assets was that there were to be divided equally." See also Mansfield v. Mansfield assets was that there

100 Lord Hodson in National Provincial Bank case, supra, n. 97 at 1220 said: "Questions have arisen in considering the extent of the discretion of the court under s. 17 of the Act of 1882, but broadly speaking the view is accepted that the court has a discretion to be exercised in the interest of the parties to restrain or postpone the enforcement of legal rights but not to vary agreed or established rights to property in an endeavour to achieve a kind of palm tree justice." See also Wilson v. Wilson, [1963] 1 W.L.R. 601 .

110 Supra, n. 22; B.C., s. 29; Man., s. 8; N.B., s. 7; Sask., s. 22; Nfld., s. 19; N.S., s. 38; Ont., s. 12 ; P.E.I., s. 13.

111 See A. F. Vassal, case comment on Thompson v. Thompson in (1961), 39 Can. Bar Rev. 432, 437.

112 Supra, in. 84 and 89 respectively.

118 (1953) 9 W.W.R. (N.S.) 316 (Manitoba). In this case the wife sought a declaration that she was the owner of a half interest in the house and an order for its sale and the equal division of the proceeds. It was held that the purchase of the house was a joint venture and each party was entitled to some half. As the property to be sold was the "the homestead" of the parties within the terms of The Dover Act, it sold was the "the homestead" of the parties within the terms of The Dower Act, it
might appear that the value of such rights should be determined pursuant to The Law of Property Act; but as they have equal rights in the homestead such calculation was unnecessary. The court also found that it was impracticable to partition and the court exercised its discretion that the property should be sold under sec. 19 of The Law Property Act, R.S.M. 1940, s. 114, as am. S.M. 1949, s. 32, s. 1.

114 (1955), 15 W.W.R. (N.S.) 301 (Manitoba). In this case also the land was the "homestead" of the parties within the terms of the Dower Act.

115 Id. at 305 .

110 (1958), 24 W.W.R. (N.S.) 625 (B.C.). 
Supreme Court of Alberta in Jackman v. Jackman ${ }^{117}$ that the wife holds the property on a resulting trust for her husband and herself if the property, which was a family asset acquired for the joint use of the spouses, was bought in a wife's name. In these cases the presumption of advancement was rebutted. The Supreme Court of Canada, however, reversed the decision of the Alberta Supreme Court in Jackman v. Jackman ${ }^{118}$ and held that the presumption of a gift was not rebutted and that wife was the beneficial owner as well as the legal owner of the property.

It is submitted that, in the above cases, the true position seems to be that it is presumed initially to be a gift if the contributions are made by the husband to property placed in the wife's name and likewise, it is presumed initially to be a resulting trust if the contributions are made by the wife to the property placed in the husband's name. But these presumptions, in their form, may be rebutted by evidence from which it can be inferred that it was the intention of both parties that each should have a joint interest in the property, regardless of the amount of individual contributions and legal ownership of the property. In such cases the legal owner holds the property on trust for both spouses jointly. ${ }^{110}$

The Supreme Court of Canada has refused to accept the joint assets doctrine and thus the weight of these cases namely Rimmer v. Rimmer, Fribance v. Fribance and Sopou v. Sopou ${ }^{120}$ has been considerably weakened in Canada. Judson J. in Thompson v. Thompson said: ${ }^{121}$

If a presumption of joint assets is to be built up in these matrimonial cases, it seems to me that the better course would be to attain this object by legislation rather than by the exercise of an immeasurable judicial discretion under section 12 of the Married Women's Property Act.

What then are the legal results? The exercise of wide judicial discretion has been limited in the common law provinces of Canada. This would lead to certainty in the law. Mackay J.A. in a dissenting judgment in the Ontario Court of Appeal in Thompson v. Thompson said: ${ }^{122}$

It seems to me that if the principle referred to by Lord Evershed in Rimmer v. Rimmer as 'palm tree justice' were to be applied to determine the real property rights, it would be likely to give rise to much uncertainty in regard to the title and ownership of land, in that different Judges might well have different ideas as to the moral justice of a case and there are no established rules to guide Judges in the application of such a principle as in the case in applying established legal and equitable principles.

It would now seem that in property disputes between husband and wife, the courts would apply the same strict rule of law and equity

117 (1958) 25 W.W.R. (N.S.) 131; [1958] 15 D.L.R. (2d) 106.

118 Supra, n. 73.

119 See B. D. Inglis, op. cit. supra, n. 70, at 539.

120 Supra, nn. 84, 89 and 116

121 [1961] S.C.R. 3, 14; (1961) 26 D.L.R. (2d) 1, 10. Much has been said and written on Thompson v. Thompson. For comment see (1961), 39 Can. Bar Rev. 432, 440, 445, See Also Anna F. Wooton. Judicial Discretion in the Division of Matrimonial Assets (1959-63). 1 U.B.C. Law Rev. 452, 460 where it was said, "It may be argued that the Thompson case is of limited application because of its special facts and that the more general remarks of $\mathrm{Mr}$. Justice Judson are obiter dicta only. . It is to be hoped. more general remarks of Mr. Justice Judson are obiter dicta only . It is to be hoped, for certainty in the law, has not closed the door completely on the occasional exercise of a reasonable judiclal discretion in a field of the law which, it is submitted, particularly calls for a certain humanity and flexibility of approach." See also supra, n. 21. But see Barleben v. Barleben (1964), 46 W.W.R. 683 (Alta. S.C.) where the parties held themselves out to be man and wife, though not married, and acquired property as joint tenants. Although she did not contribute any actual cash towards property as joint tenants. Although she did not contribute any actual cash the joint the purchase price of the lands, she contributed money and services for the joint benefit of herself and the respondent (i.e. husband). The purchase of the real estate
was also for their joint benefit. In this case, each of the parties was declared to be the legal owner of one-half share and interest in the real estate. Rimmer v. Rimmer and Fribance v. Fribance were followed.

122 (1960), 22 D.L.R. (2d) 504, 533. 
which would be applied in a contest between strangers, subject to the presumption of advancement or resulting trusts. Thus in Women's Property Act: Re Stajcer and Stajcer ${ }^{23}$ it was held by the Supreme Court of British Columbia that a wife has no claim to an interest in the home if she has not made any financial contribution to the purchase of the matrimonial home, though she may have contributed from her wages towards housekeeping money used for the food and clothing for herself and her children. A clear statement of the law is given by Trueman J.A. in the judgment of the Court of Appeal for Manitoba in Kropielnicki v. Kropielnicki124 where he said:

In Darkin v. Darkin ...., where moneys of the wife invested in their joint names were applied in purchase of real estate, which was conveyed to the husband alone, it was held that he was to be presumed a trustee for her in the absence of evidence of a contrary intention. So in Mercier v. Mercier .... where a joint banking account was kept on which each had power to draw, though substantially the whole of the moneys belonged to the wife, and a house was purchased and conveyed to the husband, the purchase-money being paid out of the joint account, and the parties residing therein till the husband's death, it was held that in the absence of evidence of gift there was a resulting trust to the wife.

The law is stated as follows in Ward v. Ward . . by Kelly, J.:-

'Where a wife hands over to her husband property belonging to her for her separate use without any intention of making a gift of it to him, he is a trustee of it for her: Green v. Carlill ...; In re Flamank ...; Mercier v. Mercier ... This does not apply where there is evidence of a contrary intention: Marshal v. Crutwell. ...?

\section{Conclusion}

The separate property system, which originated in England has been followed in Canada, India and Singapore. Though there are a wide variety of remedies for the property disputes of the spouses, they often produce peculiar injustices, but in England one can see recent legislation to remedy such injustice. The courts in England have limited the wide powers that have been conferred under section 17 of the Married Women's Property Act, 1882. The courts have no power to vary established or agreed rights. The courts at least in England will apply 'palm tree justice' where no definite intention as to the manner of ownership is ascertainable. The law therefore favours a careful spouse who throughout all the marriage puts everything in his name making the intention very clear that the property belongs to him. ${ }^{125}$ Although there are systems ${ }^{126}$ in other countries regulating the property rights of the spouse, the separate property system is much better in that it gives each spouse the complete administration and disposal of his respective property. It works well if the wife has assets of her own or if she can earn money, but if she has no assets and has to stay at home and look after the house and family, she will have no earnings or savings which she could call her own and there will be nothing to divide when the marriage is terminated. She can lay no claim to property in which her husband invests his savings or in which she invests savings from the housekeeping allowances. ${ }^{127}$ But in England, under the Mar-

123 (1961), 34 W.W.R. (N.S.) 424; See also Barleben v. Barleben, supra, n. 123, and Nemeth v. Nemeth, [1967] 64 D.L.R. (2d) 377 (B.C.S.C.) where Rimmer v. Rimmer was not followed.

124 [1935] 2 D.L.R. 100, 104. Approved in Nemeth v. Nemeth, supra, n. 125.

$125 \mathrm{H}$. Summerfield. Matrimonial Property: Too much law and Too Little Justice? (1967), 111 Sol. J. 122.

126 See Royal Commission on Marriage and Divorce, op. cit. supra, n. 52, at 392, where the various systems have been explained.

127 Supra, n. 46. 
ried Women's Property Act, 1964, any surplus or savings from the housekeeping allowance and also any traceable proceeds thereof now belong to the parties equally. Even today, the wife has no right to claim a share in a business of the husband if she helps him, unless it is a partnership business, for marriage is not a joint venture, and so the "fruit of the success is not shared." On the other hand, she would be entitled to claim something for her services. ${ }^{128}$

It is submitted that the present uncertainty about the scope of judical discretion ought to be removed as far as possible. It is suggesed that the reform in Scandinavian countries which provides for the equal division of the matrimonial property on divorce should be followed. Under this system, the property of both spouses remains entirely separate during marriage with full independence and equality on the part of both to administer their property, while, on the dissolution of marriage, the matrimonial property other than certain gifts or other property declared separate is equally divided between the spouses. ${ }^{120}$ This will ensure freedom for the spouses to deal with their affairs and at the same time make reasonable provision for the wife, if she is the nonearner, at the termination of the marriage. It might be concluded in the words of Judge Pederson, ${ }^{130}$ "The questions that have to be solved in matrimonial property law are complicated, and any system that wants to solve them cannot avoid a certain degree of complexity. Simplicity, on the other hand, may well have to be bought at the expense of the spouses, especially at that of the wife". In Canada, a well drafted legislative enactment based on the modern social conditions will be most welcome.

128 Strachan v. Strachan, supra, n. 86 . of property. The new Act has provisions to change the type of matrimonial property system under which the spouses were married. They may modify and choose another form of community or adopt separate property system or undertake a new system called Regime de Participation aux Acquets. Under the Participation system, each spouse may administer and dispose of their respective assets, and if there are any savings made by the spouses, these become common property. It combines the advantage of separate property with those of common property. There are provisions which have been laid down to arrive at some sort of equality on the termination of the marriage. See changes in French Matrimonial Law, in (1967), 111 Sol. J. 247. In New Zealand, the courts have now wide powers in settling disputes between In New Zealand, the courts have now wide powers in setting disputes between rights are, however, still discretionary by order of the court. Matrimonial Property Act, N.Z.S. 1963, No.72.

130 Pederson, Matrimonial Property Law In Denmark (1965), 28 M.L. Rev. 137, 153. 